\title{
Confessional policies of the Russian empire with respect to religious minorities $(1721-1905)^{\star}$
}

\author{
A. S. Palkin \\ Ural Federal University, \\ 51, ul. Lenina, Ekaterinburg, 620000, Russian Federation
}

For citation: Palkin A.S. Confessional policies of the Russian empire with respect to religious minorities (1721-1905). Vestnik of Saint Petersburg University. Philosophy and Conflict Studies, 2018, vol. 34, issue 2, pp. 311-320. https://doi.org/10.21638/11701/spbu17.2018.214

Russian state had multinational and polyconfessional character almost from the very beginning of its existence. From the 16th till the end of the 19th century it had to solve a problem of increasing religious diversity. The aim of the article is to find and analyze factors, which influenced relations between the state and religious minorities on the territories of the Russian empire. Over the course of research the following factors were found: the expansion of Russian territory and the inclusion of new peoples from the 16th to the 19th centuries, the relationship between the secular authorities and the official Church, the presence of a hierarchy of more or less harmful religious minorities, shifts that emerged when new monarchs and bureaucrats became occupied with questions of confessional management, and specific local conditions that were sharply distinct in the various parts of the empire. The article discusses duality and contradictions in religious policy of the Russian empire when two trends coexisted simultaneously, namely the trend toward unification of religious life of the country to improve stability, on the other hand, the trend toward religious toleration to decrease tensions and increase the loyalty of religious minorities. The paper also discusses factors influencing the formation of religious toleration towards religious minorities in different regions. The article concludes that, despite all contradictions, the religious policy of the Russian empire was successful. The manifesto of 1905 relieved tensions in relations between the state and religious minorities, and the religious question did not play significant role in the revolution of 1917.

Keywords: confessional policy, religious policy, Russian empire, Russian Orthodox Church, religious minorities, religious dissent, secularization.

The aim of this article is to conceptually emphasise the important factors that influenced the confessional policies of the Russian Empire towards its religious minorities throughout the $18^{\text {th }}$ and $19^{\text {th }}$ centuries. This chronological framework has been chosen because the Petrine era marked the period when imperial administrative structures and the Synodal system of managing the Russian Church were developed. And, in 1905, a range of laws concerning strengthening religious toleration were passed and the confessional policies of the empire underwent significant changes, an analysis of which requires separate attention.

* The work was supported by the Russian Science Foundation (RSF), grant 17-18-01194.

Исследование выполнено при поддержке гранта Российского научного фонда проект № 1718-01194 «Религиозное большинство и меньшинство в публичном пространстве России и Северной Европы: историко-культурный анализ».

(c) Санкт-Петербургский государственный университет, 2018 
The confessional policies of the Russian Empire towards religious minorities were conditioned by the effects of the following factors: 1) the expansion of Russian territory and the inclusion of new peoples from the $16^{\text {th }}$ to the $19^{\text {th }}$ centuries, 2) the relationship between the secular authorities and the official Church, 3) the presence of a hierarchy of more or less harmful religious minorities (from the point of view of the state and the official Church) [1, p.91], 4) shifts that emerged when new monarchs and bureaucrats became occupied with questions of confessional management, and 5) specific local conditions that were sharply distinct in the various parts of the empire [2].

One of the most important factors that influenced the confessional policy of Russia was the country's expansion and the growth of religious plurality. Both processes continued largely throughout the period, concluding only at the end of the $19^{\text {th }}$ century. Practically from the very beginning of its existence, the Russian state was multinational and multi-confessional in character. With time, religious diversity only grew: the annexation of Kazan and Astrakhan, the conquest of the Bashkir and Ural lands, and expansion into Siberia led to growth in the number of Muslims and adherents to traditional pantheist faiths. In the middle of the $17^{\text {th }}$ century, a schism occurred in the Russian Orthodox Church when a considerable part of the population refused to accept the reforms of Patriarch Nikon and split from the official Church. By the beginning of the $18^{\text {th }}$ century, the number of Western Christians (Catholics and Protestants) sharply increased and began to play an important role in the political, economic, and social life of the empire. The conquest of the Baltic states, Poland, and Finland in the $18^{\text {th }}$ and early $19^{\text {th }}$ centuries led to a still greater increase in the number of Catholics, Greek Catholics (Uniates), Protestants, and Jews. When the Caucasus and Central Asia were incorporated into the empire in the $19^{\text {th }}$ century, the number of Muslims rose. The growth of the empire's religious diversity was connected not only with the widening of the borders, but also with internal processes occurring within the country. For instance, the number of Old Believer communities constantly increased, and new 'sectarian' movements arose (Dukhobortsy, Molokane, Skoptsy, etc.).

The aforementioned changes led to the fact that, according to some statistics, the Orthodox stopped being the absolute majority of the empire's population by the beginning of the First World War. They numbered about as many as all the other confessions taken together. The growth of diversity was considered in the $19^{\text {th }}$ and in the beginning of the $20^{\text {th }}$ century to be a problem threatening the integrity of the empire [3, p. 25-28].

The way in which the secular authorities dealt with the problem of religious diversity was twofold. On the one hand, it was considered a norm that a person would stay in the faith in which he or she was born. On the other, the Russian Empire was an Orthodox state where conversion from non-Christian confessions to Christianity (and from nonOrthodox religions to Orthodoxy) was encouraged [4, p. 7]. This dual approach was also conditioned by a totality of various factors which we will describe below.

An important factor was the fact that the majority of the imperial elite and the monarchs themselves belonged (officially at least) to the Orthodox confession. However, from the time of Peter I, secularisation and Europeanisation of the Russian elite, increased influence of foreigners on political life, the spread of concepts of the common good (which from Peter's time was understood as the good of the state), benefit to the state, and religious toleration meant that, in the $18^{\text {th }}$ century, the state related quite tolerantly to religious minorities so long as they did not agitate against it. Besides this, policies towards 
a religious group were defined by its place in the rating of the harmfulness of religious minorities.

The least persecuted were the officially recognised confessions: Catholics, Protestants, Muslims, and pantheists. They could freely confess their faiths. The daily rituals performed by the servitors of these religions were equated to the corresponding Orthodox rites: moreover, documentation was often maintained in national languages and with the use of the corresponding alphabet (for instance, Latin for Catholics and Arabic for Muslims). The members of the Christian faiths had a very limited right (compared to the official Church) to preach among the non-Christian populations, while the adherents of non-Christian confessions were deprived of this right [1, p.91].

Jews had very limited rights: they were compelled to reside in the Pale of Settlement for most of the period under review. Settlement outside the Pale was only permitted to Jews on the condition of accepting Christianity [5].

The position of the Old Believers was extremely interesting. They did not have the status of an individual confession. Officially, they were counted as Orthodox who had departed to the schism and broken organisational links with the Church. As such, the daily rituals performed by Old Believer priests and preceptors did not have a legal status in the eyes of the secular and ecclesiastical authorities. The Old Believers themselves were divided into more or less harmful concords. The basis for this division was whether the Old Believers recognised marriage and whether they prayed for the tsar. Those who did so had more rights than those who did not. The state was least inclined to tolerate the so-called "sectarian" movements (the Skoptsy, Molokans, Dukhobortsy, and others) [6].

With such religious diversity, the protection of official Orthodoxy's status as the predominant religion was considered by both the secular and ecclesiastical elites as a necessary condition for supporting the empire and legitimising imperial authority. This was especially so in cases where the legitimacy of the ruling monarch was debated, as it was for Catherine II: she was compelled to constantly confirm her Orthodoxy in public [7; 3, p. 115-117]. The predominant status of the Russian Orthodox Church was shaped historically and strengthened by legal means. 'Apostasy' from Orthodoxy to another faith (especially a non-Christian one) was considered a deeply criminal act. The state punished especially severely the "tempters", preachers of non-Orthodox religions trying to incline the Orthodox to convert to another faith [8].

At the beginning of the $18^{\text {th }}$ century, the state in many ways managed to subordinate the Orthodox Church by abolishing the patriarchate and creating the Most Holy Synod (in reality, the state department of the Orthodox confession). The secularisation of church lands conducted by Catherine II in 1764 strengthened the Church's dependence on the state. At the same time, however, the state was compelled to consider the Church as an organisation that fulfilled a range of important functions for the secular government (for example, registering the births, deaths, and marriages of the majority of the population) and guaranteed ideological support. In reality, the network of Orthodox parishes that spread into the most distant corners of the country was the most suitable means for translating the messages of the authorities to the people.

It was connected with this that the duality of the state's confessional policies towards religious minorities arose. From the $18^{\text {th }}$ century, state actors and officials, as a rule, took a softer and more restrained position towards non-Orthodox and non-Christian communities than the men of the Church. In the $19^{\text {th }}$ century, there were also often cases where 
governors entered into conflict with the local prelates because of differences in their approaches to religious minorities [9].

Thus, there coexisted in parallel two directions in the state's religious policy: one implied that the empire would be strengthened by striving for the unification of subjects' religious lives (this was strongly supported by the Church) while the other suggested limited toleration to those confessions recognised as a harmless to the existing state order (elements of this policy appeared in the Petrine era and gathered steam in the second half of the $18^{\text {th }}$ and first quarter of the $19^{\text {th }}$ centuries). This tolerance was conditioned not only by the spread of the humanist ideas of the Enlightenment and the secularisation and religious indifference of the secular elite, but also by the attempts of the state to use the economic potential of religious dissidents and to facilitate their deradicalisation and increased loyalty [10, p. 40-50]. The influence of these two tendencies in confessional policy changed over time. In general, it is possible to emphasise several characteristic periods.

The first period stretched roughly from 1700 to the beginning of the $1760 \mathrm{~s}$. On the one hand, in 1702 Western Christians received the right to freely confess their faiths [11], the Old Believers obtained the right from 1716 on the condition that they paid the double poll tax [12] (it is also possible, however, to consider this measure as a means of stimulating conversion from the "schism" to official Orthodoxy) ${ }^{1}$. On the other hand, the state actively defended the predominant position of the official Church whilst also subordinating it in organisational terms to secular institutions. In general, in this period the tendency of unifying the religious belonging of the subjects of the Russian emperor was predominant. The evidence for this lies in the numerous repressive measures taken by the state against religious minorities.

We might consider, for example, the destruction of the Old Believer centres in the Volga region, the increased pressure on Pomor'e, the first expulsion from Vetka, and the persecution of Urals Old Believers organised by V.N. Tatishchev [15; 16, p.67-82; 17, p. 288-404]. In this period, the Muslims and pantheists of the Volga and Urals regions were subjected to forced Christianisation, which led to a series of uprisings [18]. Conversions from Orthodoxy to other faiths were persecuted especially harshly. So, for instance, in 1738 the Tatar Toigil'da Zhuliakov was burnt alive for first accepting Orthodoxy and then converting back to Islam; the Bashkir woman Kisiabika Bairiasova was subjected to the same in 1739 [19, p. 54]. In 1738, Captain Voznitsyn and Borukh Leibov, the Jew who "tempted" him to Judaism, were also burnt [20, p. 165-167]. Prince M. A. Golitsyn, who converted from Orthodoxy to Catholicism, had an unenviable fate: on the order of Empress Anna Ioannovna, he had to perform as court jester between 1732 and 1740, after which he was compelled to retire [21].

The second period lasted from the 1760s to the middle of the 1820 s. The epoch of "enlightened absolutism" and the period following it were characterised generally by a tolerant approach to the adherents of religious minorities. Catherine II herself was a proponent of religious toleration, as is evidenced by three articles (494-496) in her remarkable "Instruction" [22, p. 134] and the Senate edict of 1773 [23], which reminded people of the need for religious toleration.

${ }^{1}$ However, this measure did not work very well. In late 1720s in Nevyansk - one of the most important centers of Old Believers in the Urals - 29 Old Believers were counted officially. Actually there were at least several hundred of them. And by 1726 only one Old Believer was registered in huge Siberian guberniia [13, p. 122]. Double taxation was cancelled in 1782 [14, p. 33]. 
With the manifestos of Peter III and Catherine II, the Old Believers were permitted to return from abroad and settle in Russia[24]. The state also legitimised the positions of a range of confessions: the Protestants and Catholics received reglaments, while the Orenburg Muslim Clerical Assembly was created [25, p. 15; 26]. The characteristic feature of this period was the striving of the authorities to be flexible on questions of faith and confessional compromises. So, for example, as a result of many conversations, so-called "edinoverie", a religious movement for easing the conversion of Old Believers to the official Church by means of permitting them to use the old rituals and books, was created. The edinovertsy had to be obedient to the diocesan bishops and receive priests from them. The first attempts to do this took place in the late 1770s and early 1780s: the official legislative creation of edinoverie occurred in 1800 [10;27]. Old Believer writers, however, justifiably compared edinoverie with the Union of Brest in 1596 and considered it to be a cunning trap [28; 29]. It is interesting to note that Catherine II simultaneously created an 'Old Believer unia' in order to convert the Old Believers to Orthodoxy just as she was limiting the rights of the Uniates (Greek Catholics), who had been brought into the Russian Empire as a result of the division of the Polish Commonwealth. The position of the Uniates briefly improved under Paul I, who looked favourably on Catholicism, and Alexander I, who was inclined towards mysticism and ecumenicalism, particularly towards the end of his reign [30, p. 299-321]. On the whole, this period was characterised by the prevalence of the tendency in favour of religious diversity and toleration.

The third period (from the middle of the 1820s to the end of the 1850s) was fundamentally connected with the name of Nicholas I. One of the emperor's chief aims was to prevent revolution both in and outside Russia. Nicholas believed that the main way to strengthen the stability of the empire was to unify all spheres of social life, including the religious one. Under his rule, the Union of Brest was destroyed (all Uniate parishes, except those in Kholm diocese, were joined to official Orthodoxy in 1839) [30, p.322-346]. In answer to the Polish Uprising of 1830-1831, Catholic monasteries were subjected to mass closures [31].

Under Nicholas I, the largest ever persecution of Old Believers was conducted. Through this example, it is possible to demonstrate the complex character of the repressive policy through which Nicholas tried to unify the religious life of the Russian Empire. We can highlight a few basic elements in the state's actions which were used to put pressure on the Old Believers: the limitation of their civil rights; strengthening the exploitation of the Old Believer population; replacing "schismatic" administrators with Orthodox or edinoverie ones; exiling and arresting the most active representatives of Old Belief; limiting the spaces for the performance of daily rituals; struggling with deserting priests; the confiscation of Old Believer prayer buildings; and the weakening (or total destruction) of large Old Believer centres [32].

The fourth period was connected with the relative liberalisation of Russia in the 1860s and 70s. This period, as with all others, was not without its contradictions. On the one hand, indulgence was shown to the Old Believers and the press, including the ecclesiastical one, was liberalised, which allowed for the discussion of topics that would have been impossible even to mention in the first half of the $19^{\text {th }}$ century: the unification of the Russian and Anglican churches, "the needs of edinoverie" (a range of demands from the edinovertsy about widening their rights), and others [33]. A recent work by Gregory Freeze is dedicated to the dialogue between official Orthodoxy and the non-Orthodox 
confessions: he describes this process as "transconfessionalization", by which he means the strengthening of cooperation between different confessions, which resulted in various forms of reaction [34]. In the 1860s and 70s, the noteworthy missionary, translator, and teacher N.I. Il'minskii prepared a system aimed at the wider use of national languages in missionary activities and the translation of the liturgy, among other things [35].

On the other hand, in consequence of the Polish Uprising of 1863, the state became extremely suspicious of the Catholic Church and its clergy, considering them to be "the most dangerous enemies of Russia within its borders" [2, p. 176]. N. I. Subbotin, an influential professor at the Moscow Ecclesiastical Academy, had a similar view of the Old Believers [36]. Finally, in 1875 the last Uniate diocese in the Russian Empire, the Kholm diocese, was liquidated [30, p. 347-364].

The contradictory nature of the situation in the 1860 s and 70 s continued in the following period, between the 1880s and 1905. Alongside liberal measures, such as the law of 1883 that gave Old Believers a broad range of rights [37], conservative and even reactionary measures were taken. Russification in the border regions grew and bolstered an anti-semitic atmosphere. At the same time, however, the debate about freedom of conscience which had begun in the 1860s turned into one of the most discussed themes in both society and government circles by the beginning of the $20^{\text {th }}$ century: this led to the publication of the manifesto "On the strengthening of the principle of religious toleration" in 1905 [2, p. 179-207].

Local conditions, which were distinguished by their significant variety, played a great role in the formation of confessional policy. Often, the authorities published special instructions for the religious minorities in certain localities: these were distinct from the general law and even contradicted it (see, for instance, a situation with so called "edinoverie on special conditions" in Ekaterinburg and "blessed churches" among Ural Cossack troops [10, p.137-140, 272-275]). Another form of correction was the selective application of laws, when local authorities decided whether or not to apply a law depending on local conditions. For example, the authorities did not seize the Ekaterinburg Nikol'skaia Old Believers chapel in 1838 during the massive seizures that took place particularly in Russia and in the Urals [38]. As a result, we rather often observe a break between legislation and its practical realisation. This led to an obvious paradox: the continental legal system in use in Russia (based on law codes) entered into contradiction with the frequent use of precedent in juridical practice.

Local conditions often played a very important role in limiting the persecution of religious minorities. As a rule, this was conditioned by the influence of the following four factors either individually or together: economic significance, military significance, the danger of revolt, and a large number of non-Orthodox believers (in some regions, they might be the majority of the population).

The economic significance of religious minorities was defined by the taxation they paid and their role in the production of goods necessary to the state. Demonstrative of this are examples from the lives of the Old Believers in a range of Russian regions. The Old Believers of the Starodub region in the first half of the $18^{\text {th }}$ century received considerable economic and administrative benefits, while the authorities were compelled to close their eyes to clear violations of the law: this was because the region was located close to the border and the fact that it had economic significance as a trade and craft centre that paid quite a lot of tax. If they were persecuted, the residents of Starobud could flee to the territory of 
the Polish Commonwealth, which was extremely undesirable to the Russian government [39, p.11-25]. One can find analogous situations in the Olenets factories, a highly important industrial centre during the Great Northern War, and in the Urals, where labour shortages at the rapidly multiplying factories were overcome mostly with the employment of Old Believers [16, p. 68; 40, p. 7-11, 40-41, 47].

The military significance of religious minorities was clearest in the border territories. The authorities were forced to reconcile themselves with the wide autonomy of the Old Believer Cossacks in the southern Urals, where, at the beginning of the $19^{\text {th }}$ century, there was not a single Orthodox church. Even during the persecutions of Nicholas I, Generals Ermolov and Paskevich defended the Old Believer Cossacks of the Terek Host from missionaries and forced conversion to either Orthodoxy or edinoverie [41, p. 18; 42]. The representatives of other peoples possessed toleration on similar grounds, such as the Bashkir Muslims who participated in numerous wars led by the Russian Empire. In using the military potential of the Cossacks and Bashkirs, the imperial authorities always remembered that this potential could be turned against the government and feared revolt. The Bashkir uprisings of the $17^{\text {th }}$ and $18^{\text {th }}$ centuries were provoked not only by the seizure of their lands, but also by attempts at Christianisation. During the Pugachev Revolt, religious and national questions became so sharp that they led to the participation of native peoples and Old Believers.

Even in the severe times of Nicholas I, when the attempt to unify the religious life of the empire reached its apogee and the authorities combated religious dissent with harsh (and even cruel) measures, the authorities in the capital called on local officials to act with caution: besides this, even during times of religious persecution, the autocracy sought to act in accordance with the law in order not to provoke open opposition [43; 44, p. 642].

So, the authorities were forced to formulate special policies in those regions where, for historical reasons, a religious minority was in the majority (for example, in the western territories of the empire in the $19^{\text {th }}$ century, the majority of its subjects were Catholics and Lutherans). Firstly, it was simply not physically possible to persecute the majority of a region's population and, secondly, miscalculation in national and religious matters could lead to uprisings, as occurred in Poland in 1830-1831 and 1863-1864.

The German Lutheran elite in the Baltics, from the ranks of which were drawn many Russian statesmen, had many privileges. Under Nicholas, this placed the government in a paradoxical situation: when 100000 Baltic Christians converted to Orthodoxy in the 1840 s, this was warmly supported by the Church. However, this touched on the interests of the Lutheran elite and violated the existing order of things in this region [45].

A manifesto of 1905 and legislation of following years led to significant changes in religious policy of the Russian empire. Freedom of conscience, even in the way it was given, relieved tensions between the state and religious minorities. Despite all the contradictions of Russian confessional policy and difficulties caused by great variety of local circumstances and dynamic changes, the religious system of the Russian empire was quite stable. The situation between 1905 and 1917, I believe, demands special research, since circumstances changed a great deal for all confessional groups. The perception of new religious rights was not the same for all denominations, another topic that demands separate detailed research. As it is, after 1905 the question of religious minorities was not crucial and did not play a big role in the revolutionary events of 1917. 


\section{References}

1. Engelstein L. Slavophile Empire: Imperial Russia’s Illiberal Path. New York, Cornell University Press, 2009. $239 \mathrm{p}$.

2. Werth P. The Tsar's Foreign Faiths. Toleration and the Fate of Religious Freedom in Imperial Russia. Oxford, Oxford University Press, 2014. 306 p.

3. Smolitch I. K. Istoriia Russkoi tserkvi. 1700-1917 [History of the Russian Church, 1700-1917], pt. 1. Moscow, Izd-vo Spaso-Preobrazhenskogo Valaamskogo monastyria, 1996. 800 p. (In Russian)

4. Werth P. Pravoslavie, inoslavie, inoverie: ocherki po istorii religioznogo raznoobraziia Rossiiskoi imperii [Orthodoxy, inoslavie, inoverie: Essays on history of religious diversity of the Russian empire]. Moscow, Novoe literaturnoe obozrenie Publ., 2012. 280 p. (In Russian)

5. Budnitskii O.V., Dolbilov M.D., Miller A.I. Glava 9. Evrei v Rossiiskoi imperii (1772-1917) [Chapter 9. Jews in the Russian Empire (1772-1917)]. Zapadnye okrainy Rossiiskoi imperii [Western frontiers of the Russian empire]. Moscow, Novoe literaturnoe obozrenie Publ., 2006, pp. 301-340. (In Russian)

6. Bezhan E.M. Klassifikatsiia staroobriadcheskikh soglasii i sektantskikh obshchin, ikh razvitie i rasprostranenie na territorii Zapadnoi Sibiri v pervoi polovine XIX v. [Classification of Old Believers concords and sectarian communities, their development and dissemination on the territories of Western Siberia in the first half of the $19^{\text {th }}$ century]. Vestnik Omskogo gosudarstvennogo universiteta, 2007, vol. 3, pp. 87-95. (In Russian)

7. Polnoe sobranie zakonov Rossiiskoi imperii [Full Collection of the Laws of the Russian Empire]. $1^{\text {st }} \mathrm{ed}$. St. Petersburg, 1832, vol. 16, no. 11582. (In Russian)

8. Svod zakonov Rossiiskoi imperii [The Digest of Laws of the Russian Empire]. St. Petersburg, 1857, vol. 14, pt. 3, chapters 3-4. (In Russian)

9. Pochinskaia I. V. Episkop Neofit i viatskoe staroobriadchestvo v 30-40-e gg. XIX v. [Bishop Neofit and Vyatka Old Believers in 1830-1840s]. Problemy istorii Rossii [Problems of Russian History], is. 5. Ekaterinburg, Volot Publ., 2003, pp. 293-303. (In Russian)

10. Palkin A.S. Edinoverie v seredine XVIII - nachale XX v.: obshcherossiiskii kontekst i regional'naia spetsifika [Edinoverie from the middle of the $18^{\text {th }}$ to the beginning of the $20^{\text {th }}$ centuries: national context and regional specifics]. Ekaterinburg, Izdatel'stvo Ural'skogo universiteta, 2016. 338 p. (In Russian)

11. Polnoe sobranie zakonov Rossiiskoi imperii [Full Collection of the Laws of the Russian Empire]. $1^{\text {st }} \mathrm{ed}$. St. Petersburg, 1832, vol.4, no. 1910. (In Russian)

12. Polnoe sobranie zakonov Rossiiskoi imperii [Full Collection of the Laws of the Russian Empire]. $1^{\text {st }} \mathrm{ed}$. St. Petersburg, 1832, vol. 5, no. 2991, 2996. (In Russian)

13. Baidin V. I., Kliukina Iu. V. Oplot staroveriia [The Stronghold of Old Belief]. Ocherki istorii kul'tury $i$ byta starogo Nev'ianska [Essays on the history of culture and everyday life of old Nevyansk]. Ekaterinburg, Izdatel'stvo Ural'skogo universiteta, 2001. 248 p. (In Russian)

14. Varadinov N. Istoriia ministerstva vnutrennikh del. Istoriia rasporiazhenii po raskolu [History of Ministry of Internal Affairs. History of orders on the schism]. Vol. 8. St. Petersburg, 1863. 656 p. (In Russian)

15. Morokhin A.V. Arkhiepiskop Nizhegorodskii i Alatyrskii Pitirim. Tserkovnyi deiatel' epokhi peremen [Archbishop of Novgorod and Alatyr' Pitirim. The church actor in times of changes]. Nizhniy Novgorod, Knigi Publ., 2009. 272 p. (In Russian)

16. Pokrovskiy N.N. Antifeodal'nyi protest uralo-sibirskikh krest'ian-staroobriadtsev v XVIII veke [Antifeudal protest of Ural-Siberian Old Believers in the $18^{\text {th }}$ century]. Novosibirsk, Nauka Publ., 1974. 396 p. (In Russian)

17. Lileev M. I. Iz istorii raskola na Vetke i $v$ Starodube $v$ XVII-XVIII vv. [From the History of the Schism in Vetka and Starodubie in $17^{\text {th }}-18^{\text {th }}$ centuries], is. 1. Kiev, Tip. G. T. Korchak-Novitskogo, 1895. 597 p. (In Russian)

18. Akmanov I. G. Bashkirskie vosstaniia v XVII - nachale XVIII vv. [Bashkir uprisings in the $17^{\text {th }}-$ beginning of $18^{\text {th }}$ centuries]. Ufa, Kitap, 1998. 255 p. (In Russian)

19. Islam na Urale: entsiklopedicheskii slovar' [Islam in the Urals: Encyclopedic Dictionary]. Ed. by D.Z. Khairetdinov. Moscow, Medina Publ., 2009. 479 p. (In Russian)

20. Sbornik biografii kavalergardov. 1724-1762 [Collection of Cavalergard Biographies, 1724-1762], vol. 1. St. Petersburg, 1901. (In Russian)

21. Golitsyn (kniaz' Mikhail Alekseevich, prozvishche Kvasnik, 1697-1775) [Golitsyn (prince Mikhail Aleskeevich, nickname Kvasnik, 1697-1775)]. Entsiklopedicheskii slovar' Brokgauza i Efrona [Brokhaus and Efron Encyclopedia Dictionary], vol. 9. St. Petersburg, Brokgauz i Efron, 1893, p. 46. (In Russian) 
22. Nakaz imperatritsy Ekateriny II, dannyi Komissii o sochinenii proekta novogo Ulozheniia [Instruction of Empress Catherine II, given to the commission on creation of a project of new code]. Ed. by N. D. Chechulin. St. Petersburg, 1907. 334 p. (In Russian)

23. Polnoe sobranie zakonov Rossiiskoi imperii [Full Collection of the Laws of the Russian Empire]. $1^{\text {st }}$ ed. St. Petersburg, 1832, vol. 19, no. 13996. (In Russian)

24. Polnoe sobranie zakonov Rossiiskoi imperii [Full Collection of the Laws of the Russian Empire]. $1^{\text {st }} \mathrm{ed}$. St. Petersburg, 1832, vol. 15, no. 11420. (In Russian)

25. Zadvorniy V., Yudin A. Istoriia katolicheskoi tserkvi v Rossii [History of Catholic Church in Russia]. Moscow, St. Thomas Institute Publ., 1995. 32 p. (In Russian)

26. Khabutdinov A. Iu. Istoriia Orenburgskogo magometanskogo dukhovnogo sobraniia (1788-1917): instituty, idei, liudi [History of Orenburg Muslim Clerical Assembly, 1788-1917: institutes, ideas, people]. Nizhniy Novgorod, Medina Publ., 2010. 208 p. (In Russian)

27. White J. M. A Bridge to the Schism. Edinoverie, Russian Orthodoxy and the Ritual Formation of Confessions, 1800-1918: PhD Thesis. Firenze, 2014. 373 p.

28. Rossiiskaia natsional'naia biblioteka. Otdel rukopisei [National Library of Russia. Department of Manuscripts]. OSRK. Q. I. 1094. L.43; Tit. 288. L.7-7 verso. (In Russian)

29. Pichugin L. F. O edinoverii v Russkoi tserkvi (Uniia edinoveriia): polemicheskii ocherk [About Edinoverie in Russian Church (Union of Edinoverie): polemical essay]. Moscow, Arkheodoksiia Publ., 2009. 74 p. (In Russian)

30. Znosko K. Istoricheskii ocherk tserkovnoi unii: ee proiskhozhdenie i kharakter [A historical essay on Church Union: Genesis and development]. Minsk, Belarusian Exarchate, 2007. 368 p. (In Russian)

31. Vibe I. N. Katolicheskie monastyri v politike rossiiskoi vlasti v Zapadnom krae (1831-1832) [Catholic monasteries in the policy of Russian authorities in the Western Lands, 1831-1832]. Izvestiia Rossiiskogo gosudarstvennogo pedagogicheskogo universiteta im. A. I. Gertsena, 2008, vol. 70, is. 1, pp. 119-121. (In Russian)

32. Palkin A.S. Edinoverie v kontse 1820-kh - 1850-e gody: mekhanizmy gosudarstvennogo prinuzhdeniia i protivostoianie staroverov ["Common Faith" in the 1820s-1850s: Mechanisms of State Oppression and Old Believers' Opposition]. Quaestio Rossica, 2014, no. 3, pp. 86-106. (In Russian)

33. Palkin A.S. Otrazhenie evropeiskogo vliianiia v russkoi dorevoliutsionnoi dukhovnoi periodike v 1860-e - 1917 gg.: na primere zhurnala «Khristianskoe chtenie» [A reflection of European influence in Russian pre-revolutionary ecclesiastical periodicals, 1860-1917 (on the example of 'Christian Reading' journal)]. Istoricheskaia rusistika $v$ XXI veke [Russian Studies in History in the $21^{\text {st }}$ Century]. Budapest, Russica Pannonicana, 2017, pp. 216-221. (In Russian)

34. Freeze G. L. Globalization and orthodoxy in Imperial Russia. Vestnik of Saint Petersburg University, Ser. History, 2017, vol. 62, is. 1, pp. 4-17.

35. Veselovskiy N. Il'minskiy Nikolai Ivanovich. Russkii biograficheskii slovar' [Russian Biographical Dictionary], vol. 8. St. Petersburg, Russian Historian Society, 1897, pp. 100-103. (In Russian)

36. Subbotin N. I. Raskol kak orudie vrazhdebnykh Rossii partii [The Schism as a weapon of parties hostile to Russia]. Moscow, Katkov i Kº 1867.199 p. (In Russian)

37. Polnoe sobranie zakonov Rossiiskoi imperii [Full Collection of the Laws of the Russian Empire]. $3^{\text {st }} \mathrm{ed}$. St. Petersburg, 1886, vol.3, no. 1545. (In Russian)

38. Rossiiskii gosudarstvennyi istoricheskii arkhiv [Russian State Historical Archive]. F. 1473. Op. 1. D. 43. L. 377-378 v. (In Russian)

39. Pochinskaia I. V. Staroobriadcheskoe knigopechatanie XVIII - pervoi chetverti XIX v. [The book printing of Old Believers, the $18^{\text {th }}-1^{\text {st }}$ quarter of the $19^{\text {th }}$ century]. Ekaterinburg, TsNB Uro RAN, 1994. $182 \mathrm{p}$. (In Russian)

40. Yukhimenko E. M. Vygovskaia staroobriadcheskaia pustyn': Dukhovnaia zhizn' i literatura [Vyg Old Believers Desert: Spiritual life and literature], in 2 vols. Vol. 1. Moscow, Iazyki slavianskoi kul'tury Publ., 2002. 544 p. (In Russian)

41. Vitevsky V.N. Raskol v Ural'skom kazachem voiske i otnosheniia dukhovnoi i voenno-grazhdanskoi vlastei $k$ nemu $v$ XVIII $i$ XIX vv. [The Schism among the Ural Cossack troops and relations of ecclesiastical and civil-military authorities towards it, late $18^{\text {th }}$ and $19^{\text {th }}$ centuries]. Kazan', 1878. 236 p. (In Russian)

42. Rossiiskii gosudarstvennyi istoricheskii arkhiv [Russian State Historical Archive]. F. 1473. Op. 1. D. 42. L. 178-179 v. (In Russian)

43. Rossiiskii gosudarstvennyi istoricheskii arkhiv [Russian State Historical Archive]. F.796. Op. 205. D. 190. L. 79-80. (In Russian)

44. Doklad ministra vnutrennikh del Lanskogo [A report of minister of internal affairs Lanskoi]. Bratskoe slovo, 1891, vol. 2, pp. 640-646. (In Russian) 
45. Ryan D.C. The Tsar's Faith: Conversion, Religious Politics and Peasant Protest in Imperial Russia's Baltic Periphery, 1845-1870s. PhD Dissertation. Los Angeles, 2008. 397 p.

Received: 10.12.2017

Accepted: 08.02.2018

Author's information:

Alexander S. Palkin — Senior Research; alexander.palkin87@gmail.com

\title{
Конфессиональная политика Российской империи в отношении религиозных меньшинств (1721-1905)
}

\author{
А. С. Палкин \\ Уральский федеральный университет, \\ Российская Федерация, 620000, Екатеринбург, ул. Ленина, 51
}

Для цитирования: Palkin A.S. Confessional policies of the Russian empire with respect to religious minorities (1721-1905) // Вестник Санкт-Петербургского университета. Философия и конфликтология. 2018. Т. 34. Вып. 2. С. 311-320. https://doi.org/10.21638/11701/spbu17.2018.214

Российское государство практически с самого начала своего существования имело многонациональный и поликонфессиональный характер. Со времени начала стремительного расширения Московского государства во второй половине XVI в. и до завершения экспансии Российской империи в конце XIX в. Россия сталкивалась с проблемой нараставшего религиозного разнообразия, обусловленного рядом факторов. В таких условиях проведение взвешенной конфессиональной политики было одним из важнейших условий сохранения целостности страны. Целью статьи являются выявление и анализ основных факторов, влиявших на взаимоотношения государства и религиозных меньшинств на территории Российской империи. К таким факторам можно отнести почти непрерывное расширение территории Российского государства в XVI-XIX вв.; отношения между светскими властями и официальной церковью; формирование в империи своеобразной иерархии признанных и непризнанных, а также более или менее вредных инославных и иноверных конфессий; изменения, происходившие при смене монархов и чиновников, занимавшихся религиозными вопросами; местные условия, отличавшиеся значительной вариативностью в разных частях империи. В статье показана двойственность и противоречивость религиозной политики Российской империи, в рамках которой боролись тенденции унификации религиозной жизни страны для укрепления стабильности и веротерпимости для снятия напряженности и повышения лояльности представителей религиозных меньшинств. Также в статье выделяются факторы, влиявшие на складывание политики относительной веротерпимости в некоторых регионах и в отношении отдельно взятых групп верующих. На основании анализа литературы и источников (в том числе неопубликованных) делается вывод о том, что, несмотря на все противоречия, политика Российской империи была достаточно успешной. Укрепление начал веротерпимости в 1905 г. в значительной степени сняло напряженность в отношениях государственной власти и религиозных меньшинств, и религиозный вопрос не играл существенной роли в революционных событиях 1917 г.

Ключевые слова: конфессиональная политика, религиозная политика, Российская империя, Русская православная церковь, религиозные меньшинства, религиозное инакомыслие, секуляризация.

Контактная информация :

Палкин Александр Сергеевич - снс; alexander.palkin87@gmail.com 